\title{
Fungal Gummosis in Peach ${ }^{1}$
}

\author{
Daniel Mancero-Castillo, Ali Sarkhosh, Sara Sherman, Mercy Olmstead, Philip Harmon, and \\ Thomas Beckman²
}

The fungus Botryosphaeria dothidea causes the disease peach fungal gummosis (PFG), a vascular disease that limits the growth and yield of peach orchards in the southeastern United States (Reilly and Okie 1982). Additional species of Botryosphaeria, including B. rhodina and B. obtusa, have also been associated with gumming and dieback symptoms on peaches in the United States. Gummosis takes its name from the large amounts of resinous compounds (gum) that are exuded from fungal infections at lenticels or from other entry wounds on branches or tree trunks (Figure 1). Gummosis symptoms develop from nonpathogenic (abiotic) causes, such as physical or chemical injuries. Biotic causes of gummosis include larval feeding of both lesser peachtree borer (Synanthedon pictipes [Grote \& Robinson]) and peach tree borer (Synanthedon exitiosa [Say]) in the trunk. Damage due to these abiotic and biotic factors allows secondary pathogens to infect the wounds, leading to fungal gummosis. The disease is difficult to control, and peach orchards that are water stressed (Pusey 1989) or poorly managed are at a greater risk for severe disease damage.

In the southeastern United States, PFG has been reported since the early 1970s in major peach-producing areas where the damage may reduce the yields up to $40 \%$ (Weaver 1974; Biggs and Britton 1988; Beckman, Pusey, and Bertrand 2003). This disease was first reported on peach and citrus trees in Florida in 1911 by Fawcett and Burger. Taxonomy

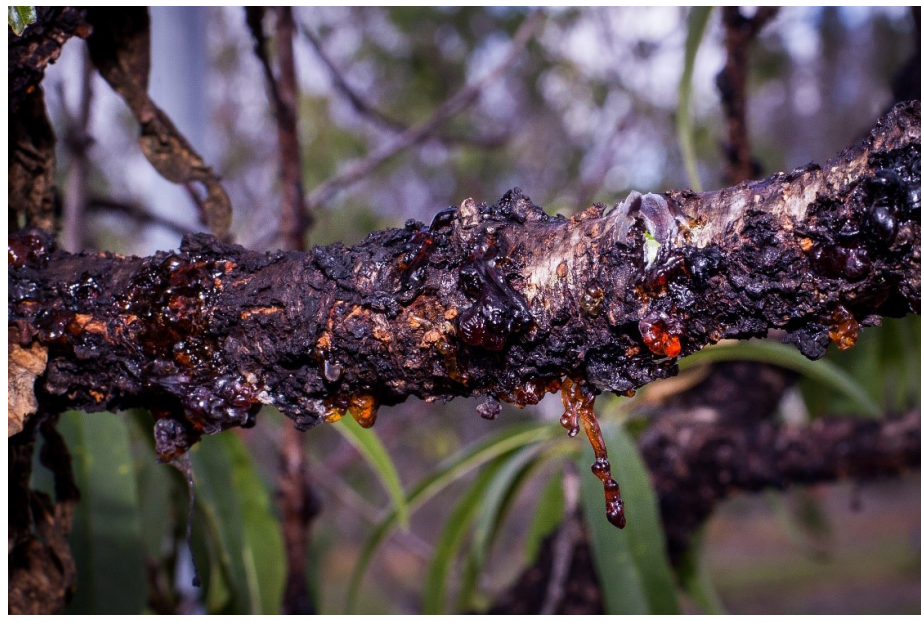

Figure 1. Peach limb with a severe fungal gummosis infection by Botryosphaeria spp.

Credits: M. Borden

of the Botryosphaeriaceae family has undergone major changes lately. Botryosphaeria dothidea is considered the most common species associated with PFG infections, but often B. obtusa and B. rhodina are found within the infected tissue. These pathogens can infect other commercial crops in the Rosaceae family and all the commercial crops in the genus Prunus, including plums (Prunus domestica L.), apricots (Prunus armeniaca L.), peaches (Prunus persica Batsch.), cherries (Prunus cerasus L.) and almonds (Prunus amygdalus Batsch.).

1. This document is HS1265, one of a series of the Horticultural Sciences Department, UF/IFAS Extension. Original publication date July 2015. Revised July 2018. Visit the EDIS website at http://edis.ifas.ufl.edu.

2. Daniel Mancero-Castillo, student; Ali Sarkhosh, assistant professor and Extension specialist; Sara Sherman, former student; Mercy Olmstead, former assistant professor and Extension specialist; Horticultural Sciences Department; Philip Harmon, associate professor and Extension specialist, Plant Pathology Department; and Thomas Beckman, research horticulturist, USDA-ARS, Southeastern Fruit and Tree Nut Research Lab, Byron, GA; UF/IFAS Extension, Gainesville, FL 32611

The Institute of Food and Agricultural Sciences (IFAS) is an Equal Opportunity Institution authorized to provide research, educational information and other services

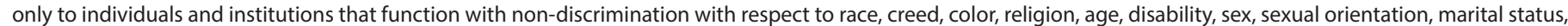

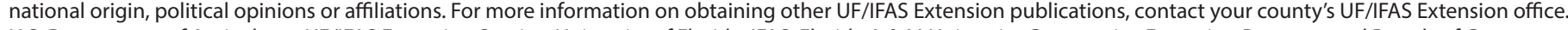
U.S. Department of Agriculture, UF/IFAS Extension Service, University of Florida, IFAS, Florida A \& M University Cooperative Extension Program, and Boards of County Commissioners Cooperating. Nick T. Place, dean for UF/IFAS Extension. 


\section{Gumming}

The characteristic gumming (Figure 2) from peach trees is a defense response by the tree to biotic and abiotic stresses (Brooks and Ferrin 1994). Gum is produced by the tree from secretory cells and decomposed cell walls following gum duct formation in the mesocarp vascular parenchyma (Morrison and Polito 1985). Peach gum is mainly composed of carbohydrates $85.67 \pm 0.37 \%$, proteins and minerals $1.74 \pm 0.04 \%$, and moisture $3.80 \pm 0.19 \%$ (Simas et al. 2008).

\section{Trunk and Branch Symptoms}

The earliest symptoms of fungal gummosis are raised blisters 1-6 $\mathrm{mm}$ in diameter that appear on the natural openings, such as stomata and lenticels, of young shoots, or near wounds (Figure 2A) (Figure 3). These blisters will generally have a lenticel at their center, which is where the pathogen, usually B. dothidea, has infected the bark (Pusey 1986; Weaver 1974). The raised blisters are caused by hyperplasia (the abnormal multiplication of the plant cells) of the peridermal and cortical cells near lenticels.

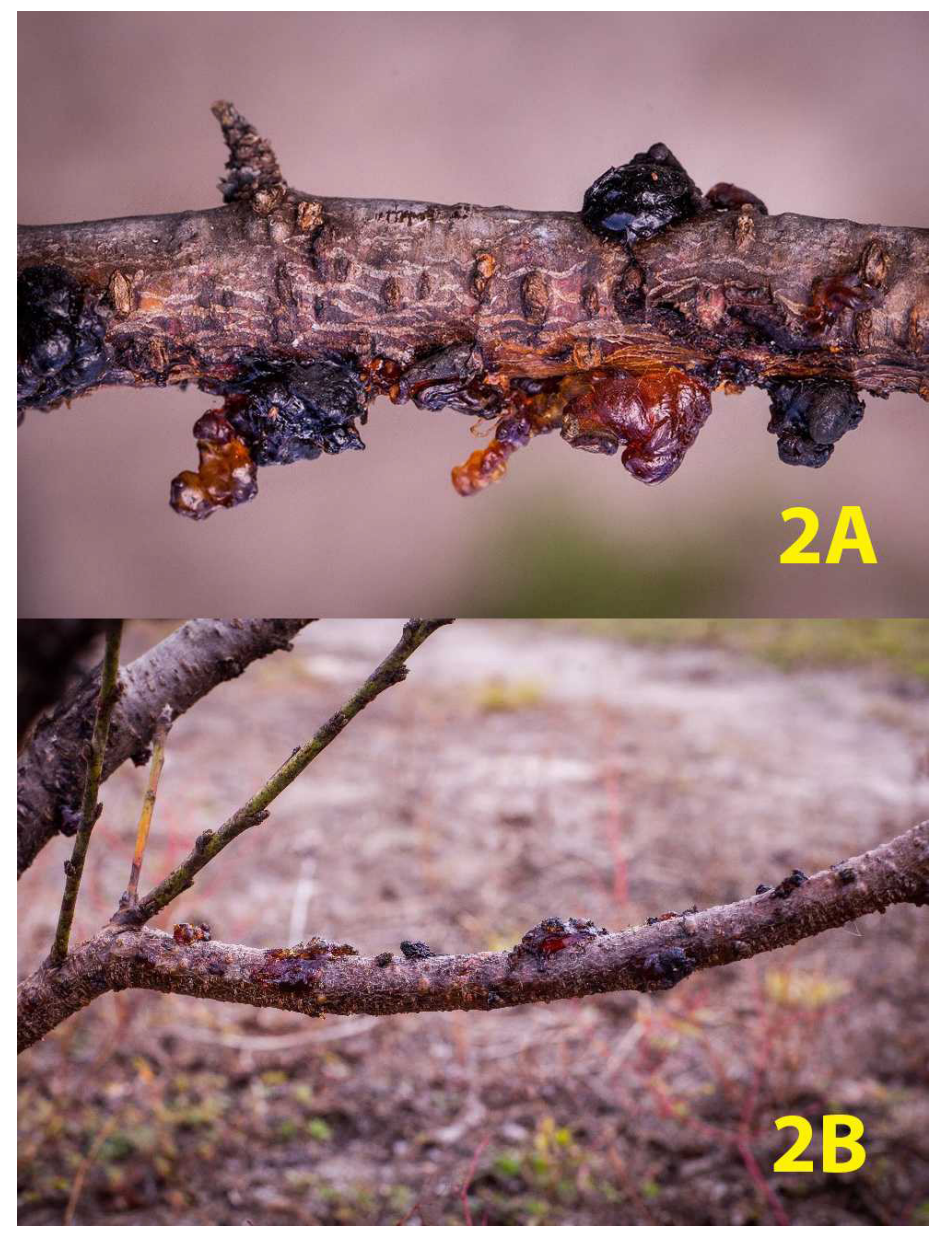

Figure 2. Two-year-old peach scaffold (2A) with swollen lenticels and gumming secretion (2B) caused by Botryosphaeria spp. infection. Credits: M. Borden
These blisters may be observed late in the season in which infection occurred or during the following year.

After initial infection, necrotic lesions in phloem and cortex tissues (Figure 2B) continue to expand under the bark. In old tissue, sunken necrotic lesions form and will frequently be sites of gum release. The most noticeable symptom of infection is the gum exudates on the stems and branches of the tree (Figure 4). Vascular clogging from

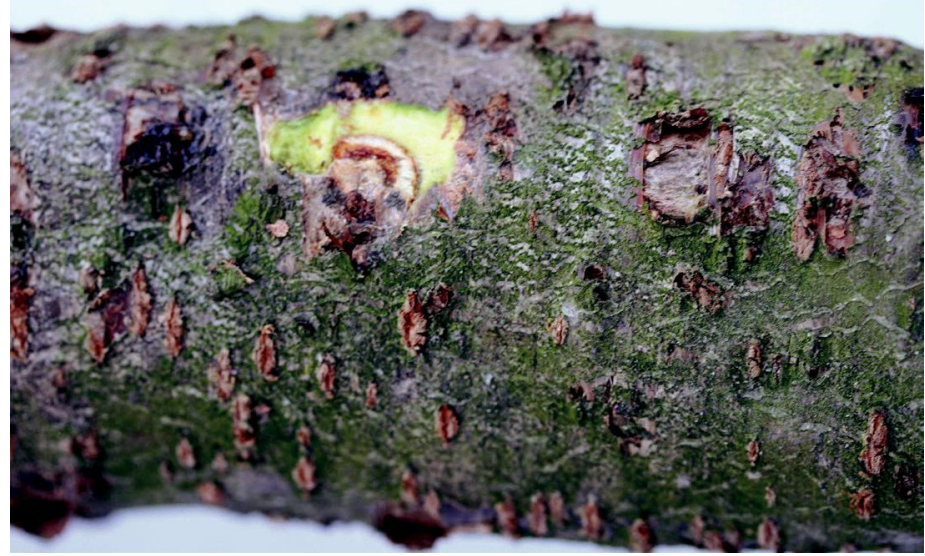

Figure 3. A peach limb with the blister symptom of fungal gummosis caused by Botryosphaeria dothidea.

Credits: L. Pusey, USDA-ARS

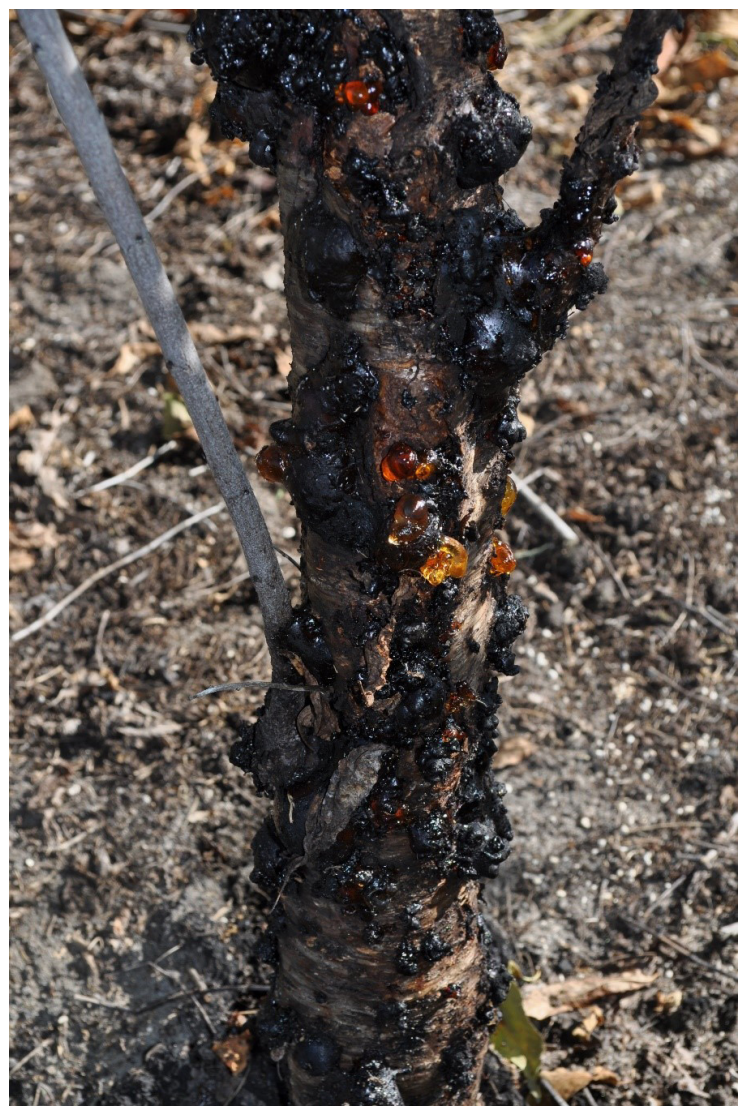

Figure 4. 'Flordaguard' peach rootstock infected with fungal gummosis showing gumming lesions and swollen lenticels. Credits: M. Olmstead 


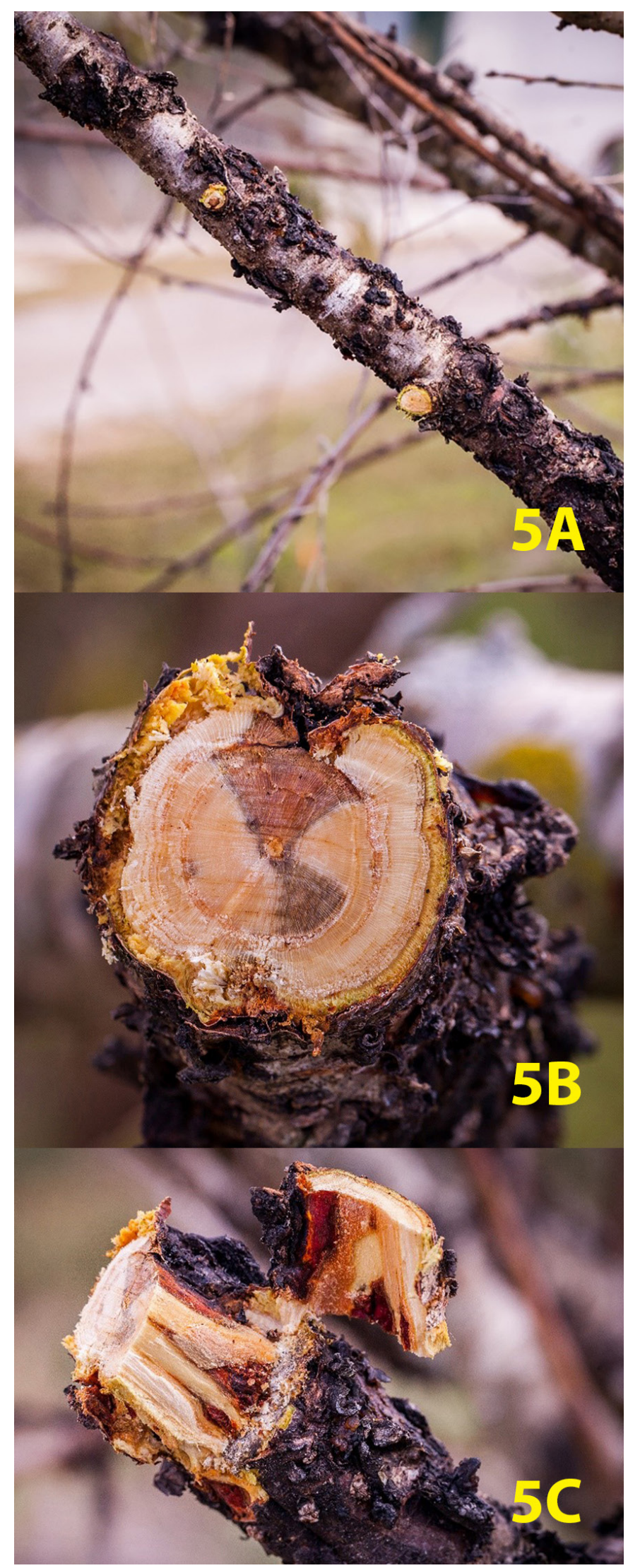

Figure 5. An infected peach branch (5A), a horizontal cut (5B), and bark partially removed $(5 \mathrm{C})$ to reveal the infection is erupting through the bark and discoloration in the phloem and xylem tissue on a Botryosphaeria diseased branch.

Credits: M. Borden pathogen infection and gumming produce limb dieback and cankers (Figure 5). Cankers can coalesce on the bark, forming large lesions on the main trunk (Figure 3). During winter months, gumming is reduced, but the scars from previous gum sites remain visible. Severely infected limbs have a very coarse periderm layer with a blackish color (Figure 1), whereas non-infected limbs have a generally smooth periderm of a grayish-silver color (Figure 2B). Peach trees with severe infections ultimately die (Pusey et al. 1995; Beckman et al. 2003). Severe PFG damage to peach orchards can lead to reductions up to $40 \%$ (Beckman et al. 2011) or 25\% (Ezra et al. 2017).

Symptoms vary depending on the season, and susceptibility to this disease is highly variable among peach cultivars (Beckman et al. 2012; Beckman and Reilly 2005). Symptoms are most visible in the southeast from June to October.

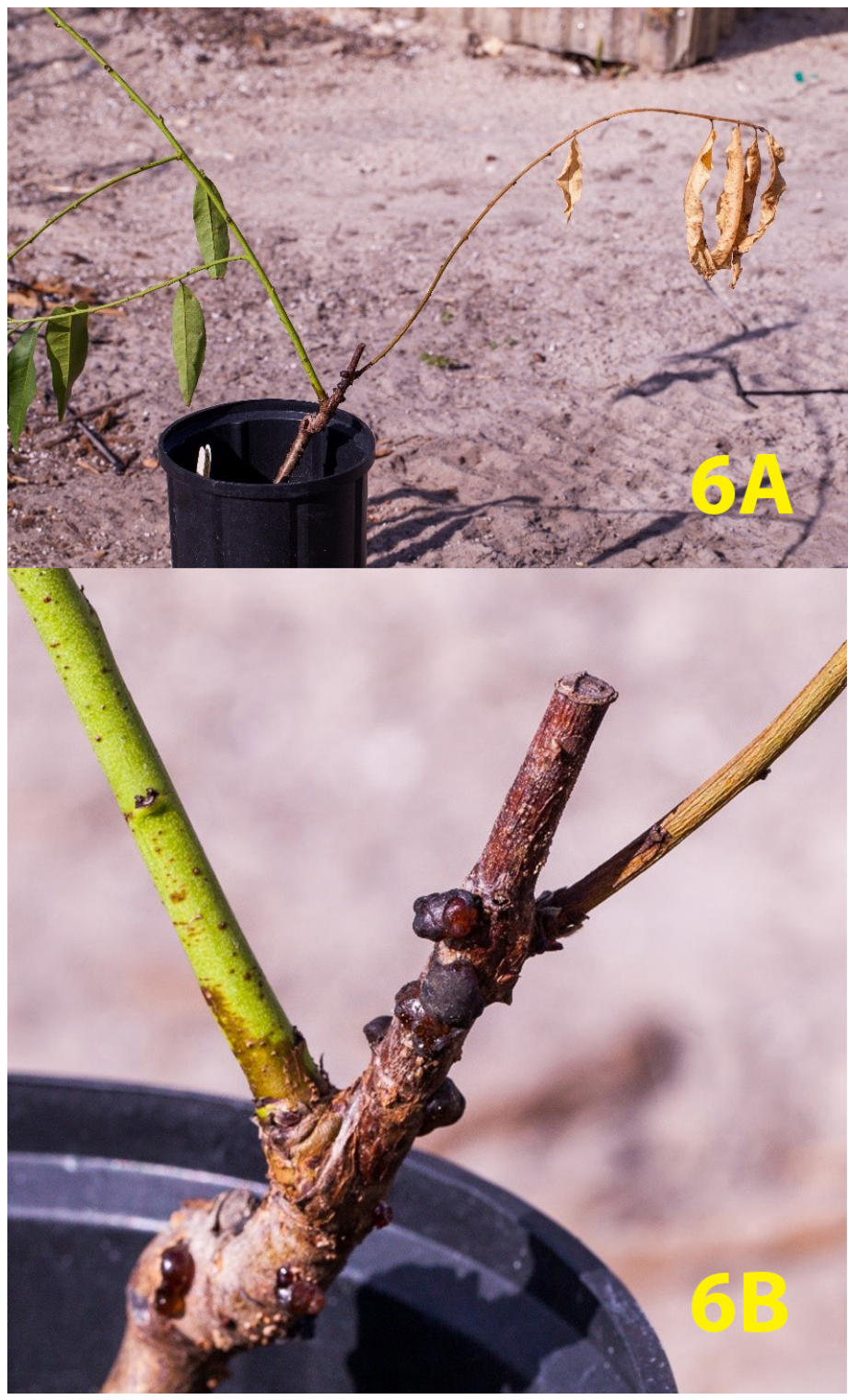

Figure 6. Grafted peach (6A) and a magnified view (6B) with gumming lesions and dieback from the top caused by Botryosphaeria species. Credits: M. Borden 
During this time, seasonal rain and high temperatures allow for the proliferation of spores and full symptom expression. The severity of symptoms can be exacerbated by periods of drought from August to October and insect or mechanical damage (Pusey 1989).

\section{Disease Cycle}

Botryosphaeria sp. inoculum varies throughout the year depending upon dispersal from the release of ascospores (sexual spores) and conidia (asexual spores) through the air and/or water. Airborne dispersal is almost exclusively from the release of ascospores (Pusey 1989). Spread of ascospores in this manner is highest from mid-March to mid-May and lowest during the winter months (Figure 7). The release of ascospores is triggered by moist conditions resulting from rainfall, dew, or mist. The highest levels of airborne dispersal occur during the day when relative humidity is lower, the temperature is higher, and air movement is typically greater (Pusey 1989). On the other hand, waterborne dispersal is a combination of ascospores and conidia. Pusey (1989) found that higher amounts of conidia from $B$. dothidea come from living plant tissue, as opposed to dead limbs.
Peach fungal gummosis can overwinter as pycnidia (asexual fruiting body filled with spores).

\section{Disease Management}

Peach fungal gummosis management is particularly difficult, because the trees can be infected at almost any time of the year and latent infections are very common. Once the disease becomes established, it is increasingly difficult to control the infection in the inner tissues (Okie and Puse 1996; Polashock et al. 2006).

Currently, there are no effective or approved fungicides to control peach fungal gummosis dieback. Fungicides applied to manage fruit and leaf diseases may also help suppress fungal gummosis, but protecting trees with fungicides during the long potential infection period each year in Florida can quickly become impractical and cost-prohibitive. Maintaining tree health with good horticultural practices can also help reduce losses due to fungal gummosis. Monitoring for symptoms routinely and managing the fertilization and irrigation system properly are recommended to reduce disease-promoting conditions.

\section{Specific Horticultural}

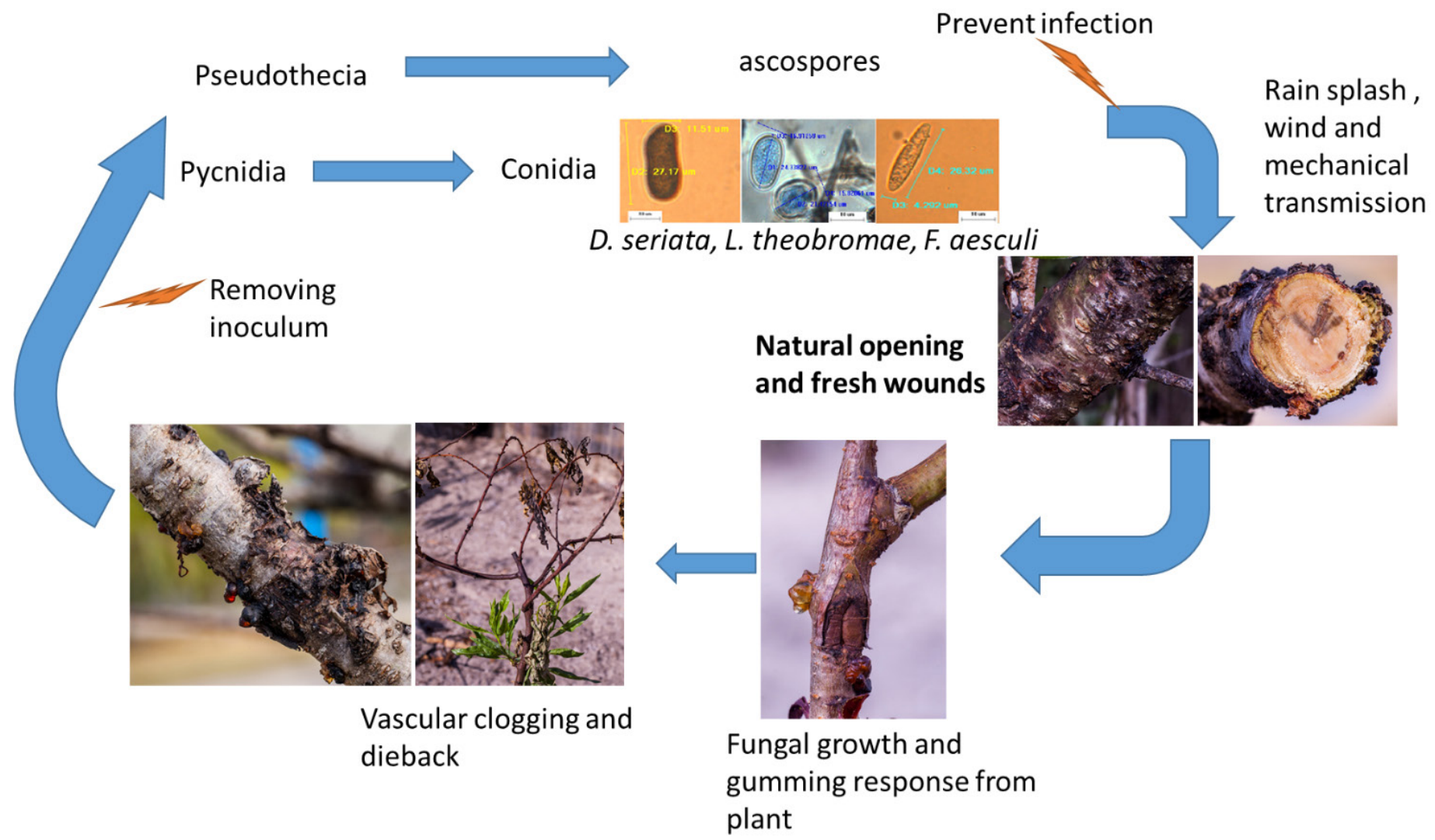

Figure 7. Peach fungal gummosis life cycle in peach trees showing the main symptoms and points where control measures can be taken, including conidia microscopic images for the three main Botryosphaeria pathogens: B. dothidea (anamorph Fusucocum aesculi), B. obtusa (anamorph D. seriata), and B. rhodina anamorph (Lasiodiplodia theobromae). Credits: D. Mancero-Castillo 


\section{Recommendations for Managing an Outbreak of Fungal Gummosis}

The pathogen that causes fungal gummosis survives and produces spores on dead and diseased wood. Use good pruning practices to remove as much unproductive and diseased wood as possible during winter pruning. Remove and destroy the pruned wood mechanically with powered agricultural equipment, such as a flail mower, to speed decomposition and reduce spore production.

In Florida, summer pruning is an essential production practice, so follow these steps to minimize the chances that spores of the $B$. dothidea are spread in the process:

- Avoid pruning immediately before or after a rain or irrigation event when the foliage is wet. Try to avoid rain or irrigation events when scheduling summer and/or winter pruning. Weather data can be found for various statewide sites using the Florida Automated Weather Network (FAWN; http://fawn.ifas.ufl.edu/).

- Avoid pruning water- and nutrient-stressed trees.

- Prune areas of the orchard, specific trees, or varieties with fungal gummosis last.

- Disinfect the pruning tools periodically, especially after cutting infected material and before moving to the next tree (which may or may not be already infected). Rubbing alcohol, quaternary ammonium solution, or $10 \%$ bleach (sodium hypochlorite) can be used for tool sanitization.

- Promote air movement through the canopy by proper pruning and removing suckers from the base of the trunks. Use peach varieties that are less vigorous and require less pruning (for more information, see http:// edis.ifas.ufl.edu/mg374). This can reduce the dispersal of the pathogen from pruning and reduces pruning wounds.

- Prune dead limbs and infected twigs only within a dry period of time, following with fungicide sprays to protect the fresh wounds.

- Orchard establishment should avoid low-lying areas with poor air circulation and soil drainage.

- Reduce cultural practices that predispose trees to infection, such as overhead irrigation after pruning or harvesting, excessive herbicide applications near the trunk, improper soil depth at planting, mechanical injuries from equipment, and inconsistent sanitation practices.

- Proper nutrient and soil $\mathrm{pH}$ should avoid excessive new shoots and growth of succulent tissues, which are prone to infection.
- Monitor trees for peach fungal gummosis symptoms using the presence of lesions on the bark from previous years to estimate the dispersal and relative disease severity.

- Monitor trees for sign or symptoms of pests such as insects, rabbits, or deer, which injure tissue and allow infection.

- Prevent infection by avoiding plant stress that predisposes tissues to infection and colonization. When possible, mitigate environmental stresses such as excessive heat, drought, freeze injury, or flooded and compacted soil.

- Prevent excessive weed growth around peach trunks to increase the air movement around the trunk. A consistent moist condition in orchards with poor weed control increases fungal growth.

- Consider altering irrigation equipment, sprinkler systems, or drip irrigation to prevent wetting the trunk during irrigation sets. Microsprinklers that spray in a fan pattern $\left(<360^{\circ}\right)$ can be optimized to prevent direct water contact. Drip irrigation systems may require two lines on either side of the tree to deliver the volume needed, depending upon the emitter.

- Implement a continuous disease management program. However, there is no fungicide registered for use on peach for peach fungal gummosis management.

Ideally, the best solution to fungal gummosis would be the development of host resistance in commercial cultivars. However, none of the varieties currently utilized in Florida display useful levels of resistance. Fungal gummosis resistance is one of the goals of ongoing breeding efforts.

\section{References}

Beckman, T. G., J. X. Chaparro, and W. B. Sherman. 2012. “'MP-29', a Clonal Interspecific Hybrid Rootstock for Peach." HortScience. 47: 128-131.

Beckman, T. G. and C. C. Reilly. 2005. "Relative susceptibility of peach cultivars to fungal gummosis (Botryosphaeria dothidea)." J. Am. Pomol. Soc. 59: 111-116.

Beckman, T. G., P. L. Pusey, and P. F. Bertrand. 2003. "Impact of Fungal Gummosis on Peach Trees." HortScience. 38: 1141-1143.

Beckman, T. G., C. C. Reilly, P. L. Pusey, and M. Hotchkiss (2011). "Progress in the Management of Peach Fungal Gummosis (Botryosphaeria dothidea) in the Southeastern US Peach Industry." J. Am. Pomol. Soc. 65: 192-200. 
Brooks, F. E. and D. M. Ferrin. 1994. "Branch dieback of southern California chaparral vegetation caused by Botryosphaeria dothidea." Phytopathology. 84: 78-83.

Biggs, A. and K. O. Britton. 1988. "Presymptom Histopathology of Peach Trees Inoculated with Botryosphaeria obtusa and B. dothidea." Phytopathology. 78: 1109-1118.

Ezra, D., M. Hershcovich, and D. Shtienberg. 2017. "Insights Into the Etiology of Gummosis Syndrome of Deciduous Fruit Trees in Israel and its Impact on Tree Productivity." Plant Dis. 101: 1354-1361.

Fawcett, H. S. and O. F. Burger. 1911. "A Gum-Inducing Diplodia of Peach and Orange." Mycologia. 3: 151.

Morrison, J. C. and V. S. Polito. 1985. "Gum Duct Development in Almond Fruit, Prunus dulcis (Mill.) D. A. Webb." Botanical Gazette. 146: 15-25.

Okie, W. R. and P. L. Pusey. 1996. "USDA Peach Breeding in Georgia: Current Status and Breeding for Resistance to Botryosphaeria." Acta Hortic. 151-158.

Polashock, J and M. Kramer. 2006. "Resistance of Blueberry Cultivars to Botryosphaeria Stem Blight and Phomopsis Twig Blight." HortScience. 41: 1457-1461.

Pusey, P. L. 1989. "Availability and Dispersal of Ascospores and Conidia of Botryosphaeria in Peach Orchards." Phytopathology. 79: 635-639.

Pusey, P. L., H. Kitajima, and Y. Wu. 1995. "Fungal gummosis." Compend. stone fruit Dis. 98.

Pusey, P. L. 1986. "Symptomatic responses of peach trees to various isolates of Botryosphaeria dothidea." Plant Dis. 70: 568-572.

Pusey, P. L. 1989. "Influence of water stress on susceptibility of nonwounded peach bark to Botryosphaeria dothidea."

Plant Dis. 73: 1000-1003.

Reilly, W. D. and W. R. Okie. 1982. "Distribution in the southeastern United States of peach tree fungal gummosis by Botryosphaeria dothidea." Plant Dis. 158-161.

Simas, F. et al. 2008. "Comparison of structure of gum exudate polysaccharides from the trunk and fruit of the peach tree (Prunus persica)." Carbohydr. Polym. 71: 218-228.
Weaver, D. J. A. 1974. "Gummosis Disease of Peach Trees Caused by Botryosphaeria dothidea." Phytopathology. 64: 1429-1432. 